\title{
LAND SUBSIDENCE DUE TO EXCESSIVE GROUND WATER WITHDRAWAL. A CASE STUDY FROM STAVROS - FARSALA SITE, WEST THESSALY GREECE
}

\author{
Rozos D. ${ }^{1}$, Sideri D. ${ }^{1}$, Loupasakis C. ${ }^{1}$ and Apostolidis E. ${ }^{2}$ \\ ${ }^{1}$ National Technical University of Athens, School of Mining and Metallurgical Engineering, \\ Laboratory of Engineering Geology and Hydrogeology, 9, Heroon Polytechniou Str 157 80, Zografou \\ (Athens)Greece,rozos@metal.ntua.gr,dsideri@metal.ntua.gr,cloupasakis@metal.ntua.gr \\ ${ }^{2}$ Institute of Geology and Mineral Exploration, Engineering Geology Department, Sp Louis Str. 1, Olympic \\ Village, 13677 Acharnae, Athens, Greece,emmapost@ath.forthnet.gr
}

\begin{abstract}
Land subsidence manifestation due to ground-water overexploitation in the Stavros - Farsala site (eastern part of Western Thessaly Basin) has been noticed since 1990. Because of this overexploitation, an excessive drawdown of the ground water level (20 to 40m) was noticed in the various successive aquifers the last decades. The subsidence phenomena resulted to the formation of tensile surface ruptures, which occurred since 2002, affecting roads and buildings.

The geological environment of the study area consists of terrestrial Pleistocene deposits containing sands and gravels interbedded with clayey silt to silty clay horizons. These alternations of aquifers (permeable coarse-grained deposits) with aquitards (impermeable to low permeability strata) create a number of successive semi-confined to confined aquifer, initially artesian. This study examines the geological and the hydrogeological conditions of the wider study area, aiming to clarify their relationship with subsidence phenomena and to provide solutions for their suspension. Note that those phenomena are expected to be more incensed during the next few years.
\end{abstract}

Key words: aquifers overexploitation, land subsidence, excessive groundwater drawdown, Thessaly Greece.

\section{Introduction}

During the years, numerous studies have been conducted globally, in areas subjected to land subsidence due to the overexploitation of aquifers (Kallergis, 1971; Andronopoulos et al., 1991; Liu et al., 2004; Xue et al., 2005; Li et al., 2006; Serva \& Brunamonte, 2007; Shi et al., 2007; Loupasakis \& Rozos, 2009). Land subsidence, triggered by excessive groundwater drawdown and resulted from the compaction of the drained loose sedimentary formations, manifests with an increasing rate during the years. The rising needs for water leads to the over pumping of ground reservoirs causing non reversible damages to the aquifers. Thessaly plain, Kalochori village near Thessaloniki, Megalopolis in Peloponnesus, Anargiri region on the southwest of Florina and Messara valley in Crete are some of the regions affected by these phenomena.

The Stavros - Farsala study area is a part of West Thessaly basin. Thessaly basin is lowland in Central Greece, with an extent of $4,520 \mathrm{~km}^{2}$, mainly drained by Pinios River. Thessaly basin is subdivided, 


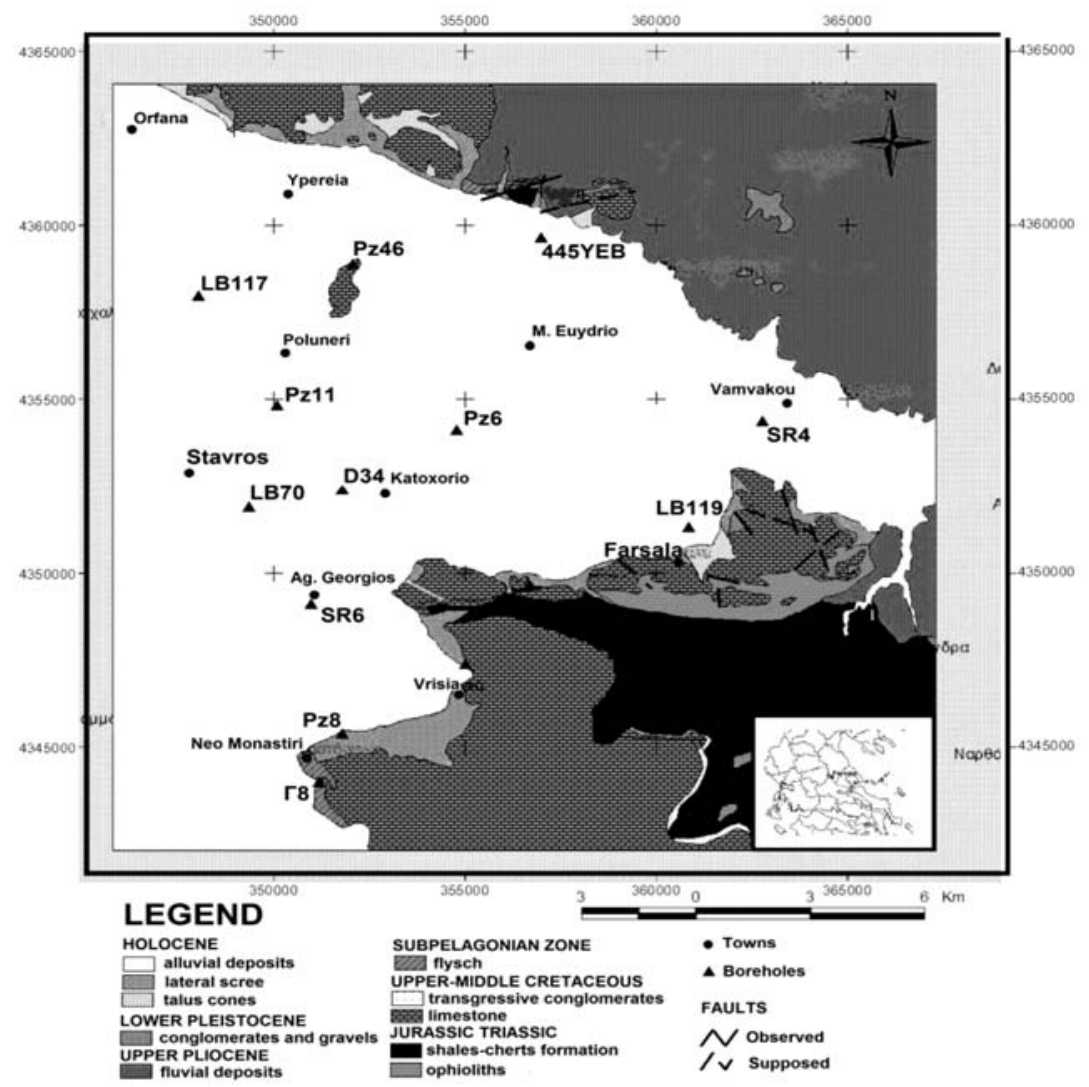

Fig. 1: Simplified geological map of Stavros - Farsala wider area. The locations of the water wells used for piezometric measurements are also presented.

by a group of hills, in two subbasins, the westerner and the Eastern. Stavros-Farsala study site is located in the eastern part of the western subbasin. These subbasins are two main individual hydrogeological units, developing high potential aquifers. The overexploitation of these aquifers led to the manifestation of extended damages due to land subsidence phenomena. This paper aims to presents the intenseness of those phenomena and to correlate them with the ground water withdrawal.

\section{Geological setting}

According to the geological map of Greece (IGME, 1969) and the field mapping conducted during the study, Mesozoic Alpine formations outcrop in the margins of the study area, while, post alpine deposits are presented in the lowland of the basin (Fig. 1). The Mesozoic Alpine formations belong to the Pelagonian (Subpelagonian) geotectonic zone and they constitute the bedrock of Quaternary deposits of Stavros - Farsala area. These formations consist of Schist-chert formation, Ophiolites, Limestones and Flysch sediments (Mariolakos et al., 2001; Rozos \& Tzitziras, 2002).

The post-alpine deposits, some of which are related with the subsidence phenomena, include:

- Neogene deposits: Fluvial and lacustrine formations, consisting of red clayey silts and cohesiveless clayey sands with scattered gravels and pebbles of various origin and semi coherent 


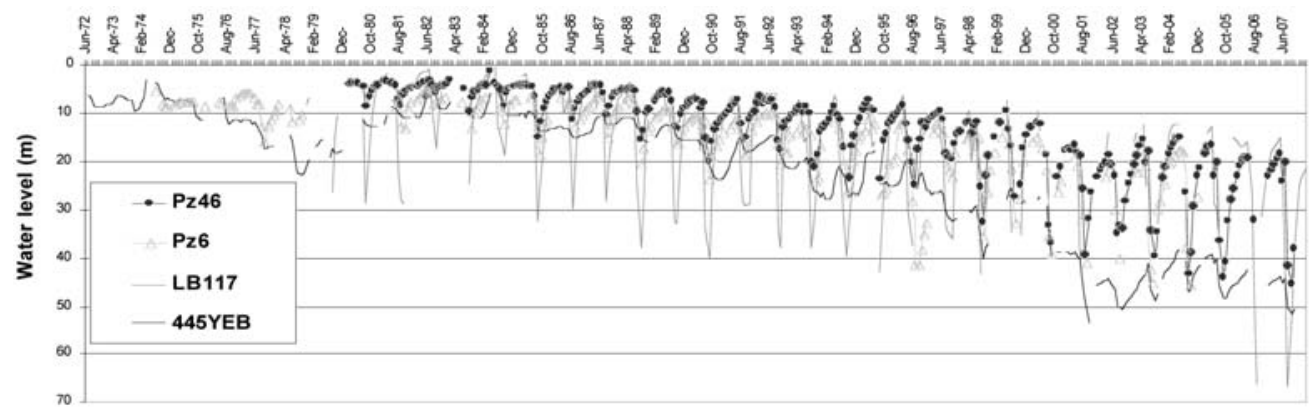

Fig. 2: Ground water table fluctuations in relation to the time in Pz46, Pz6, LB117, and 445YEB water wells.

conglomerates. The lacustrine deposits include friable gray to light gray marls in layers with a thickness of 5-20 cm, along with intercalations at places of sandstones and conglomerates (Mariolakos et al., 2001).

- Pleistocene deposits: Terrestrial formations of clayey silts, sandy silts, sandy clays and sands, with grits and gravels. These deposits appear extensive surface development at Farsala - Karditsa - Trikala basin, and gain considerable thicknesses even near the margins of that basin. Because of their lithology, they develop high potential aquifers that undergo intensive exploitation. (Rozos \& Tzitziras, 2002).

- Holocene deposits: Alluvial deposits consisting of clays to sandy clays fluvial deposits of variant thickness, depending on their origin, the paleo relief, but also on the paleo climatic conditions.

\section{Hydrogeological conditions}

The quaternary deposits contain the main aquifers of the wider study area. The aquifers constitute a system of unconfined shallow aquifers, extending in the upper layers, and successive confined artesian aquifers developing in the dipper permeable layers (Marinos et al, 1995; Marinos et al, 1997). This system besides the percolated surface water is also supplied by water through the lateral infiltration from the karstic aquifers of the alpine carbonate formations, outcropping in the margins of the basin. In general, the richest aquifers are developed in the western subbasin of Thessaly plain, due to their rich supply both from the big infiltrating part of the surface runoff and the lateral infiltration. The exploitable water potential of the above described system is about $400 \times 10^{6} \mathrm{~m}^{3}$.

In order to study the ground water fluctuation in Stavros - Farsala region, thirteen (13) water wells were monitored from 1972 to 2007 . The piezometric level monitoring data proved that during the years a sufficient drawdown of the ground water level takes place, reaching up to values of $67 \mathrm{~m}$ (Fig. 2). It appears that even if a small recharge of aquifers takes place every year during the rainfall period, the final tendency is a stable drawdown. The mean piezometric level drawdown exceeds the $40 \mathrm{~m}$ and the mean annual drawdown rate was estimated to be $60 \mathrm{~cm} /$ year. It is noticeable that the changes of the ground water level were not caused by a corresponding reduction of the mean annual rainfalls. According to the meteorological data form three local stations, namely Farsala, Domokos and Myra, the mean annual rainfalls were nearly stable during the last thirty years, with a small exception during the period 1977 to 1984 (Fig. 3). 


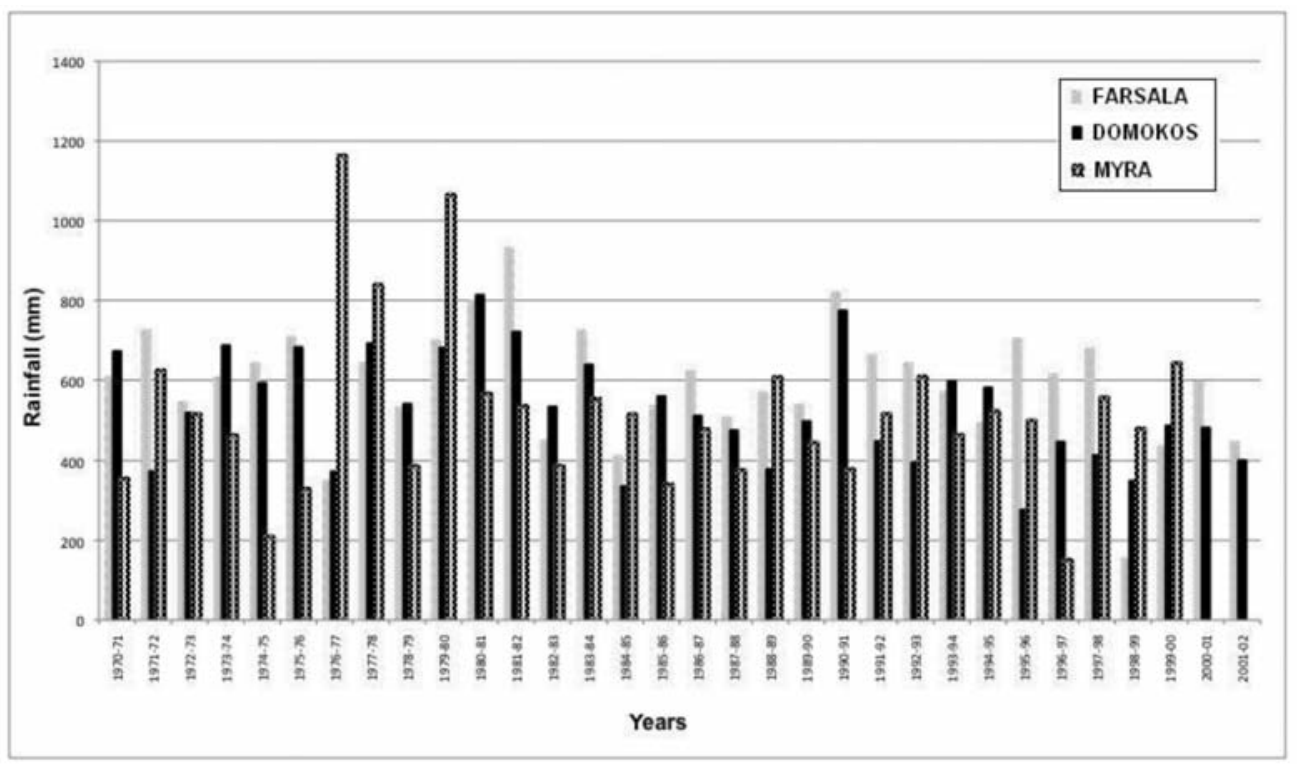

Fig. 3: Mean annual rainfall fluctuation (data from Farsala and Domokos stations of the National Meteorological Service, and Myra station of the Ministry of Agriculture).

\section{Surface subsidence ruptures in Stavros - Farsala site}

In the eastern part of Thessaly basin the land subsidences phenomena occurred for the first time in 1996 (Soulios, 1997; Soulios, 1980). With a time delay, in Farsala site, west Thessaly, these phenomena, with the form of surface ruptures, were firstly manifested in 2002. The overexploitation of the ground water resulted to the activation of the subsidence mechanism in the discharged aquifers and subsequently led to the manifestation of the accompanying phenomena on the surface, apart from the land depression.

Therefore, along the margins of the basin were the bedrock outcrops and generally in areas were the thickness of the deposits is small, fractures of the ground occur, as a result of the tensile forces action. On the contrary, in the parts of the basin with thick deposits the compaction of the formations can become noticeable by the extraction of the water well pipes from the ground.

Farsala city is built partly on the bedrock Alpine formations and partly on the Pleistocene deposits. The variations on the geotechnical behaviour of the foundation formations lead to the manifestation of numerous tensile fractures, in several sections of the town. Precisely, in the centre of the town, an area extending $50 \mathrm{~m}$ x $360 \mathrm{~m}$ (Fig. 4) was intensively damaged. The road pavements present multiple fractures, redisplayed afterwards any repair works. Also, several buildings, intersected by the ruptures, were intensively damaged requiring expensive reconstruction works. Small ground ruptures have been also presented in the northern part of the town in an area covering $180 \mathrm{~m} \times 200 \mathrm{~m}$. Also, beyond the south western limits of the town and at the west of the railway line, two more extensive ruptures were observed with total length 1,000 $\mathrm{m}$ and 2,500 $\mathrm{m}$ respectively. The northern one has a mean azimuth of about $100^{\circ}$ and shows a vertical displacement at a rate of 20 to $50 \mathrm{~cm}$. Respectively, the southern rapture, with a mean azimuth of about $110^{\circ}$, presents a vertical displacement of 15 to 


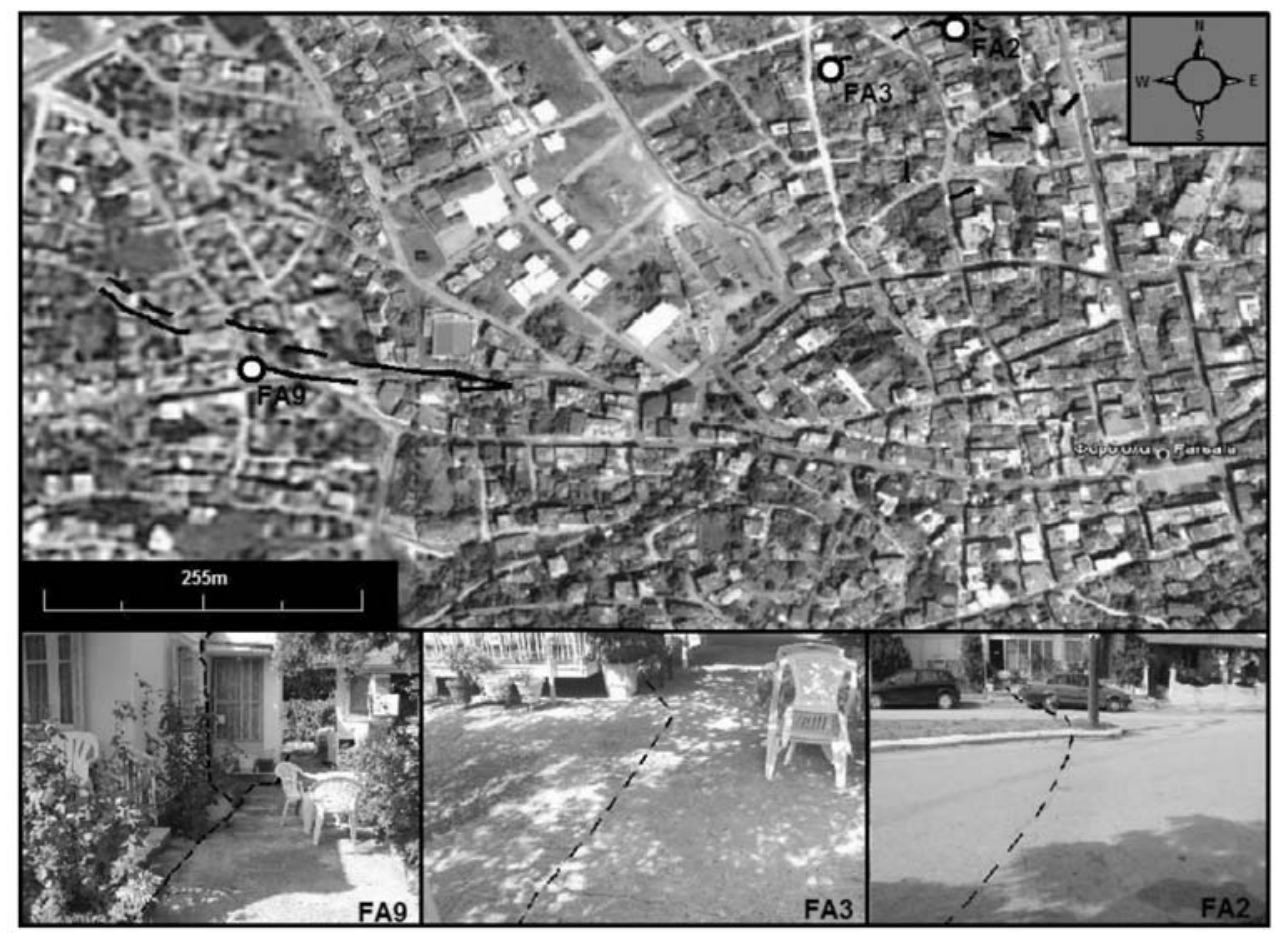

Fig. 4: Satellite pictures (from Google Earth) pointing the location of the surface raptures along Farsala town. Pictures FA2, FA3 and FA9 show roads and buildings damaged by the surface raptures.

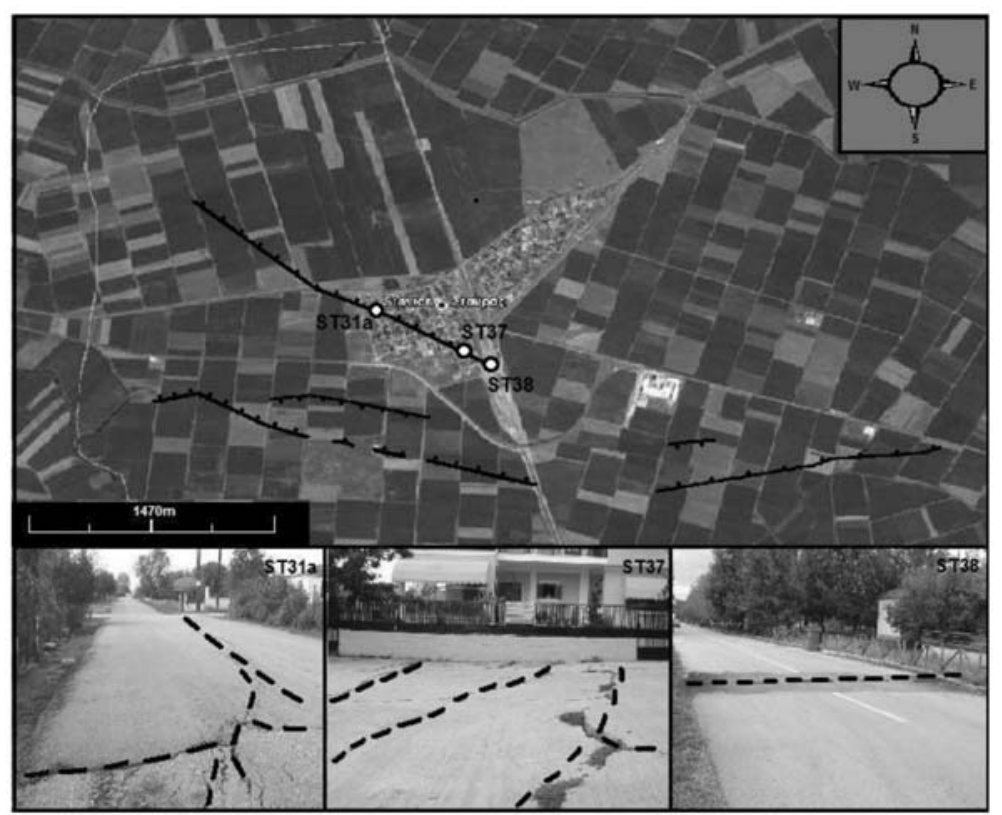

Fig. 5: Satellite pictures (from Google Earth) pointing the location of the surface raptures along Stavros town. Pictures ST31a, ST37 and ST38 present roads damaged by the surface raptures. 


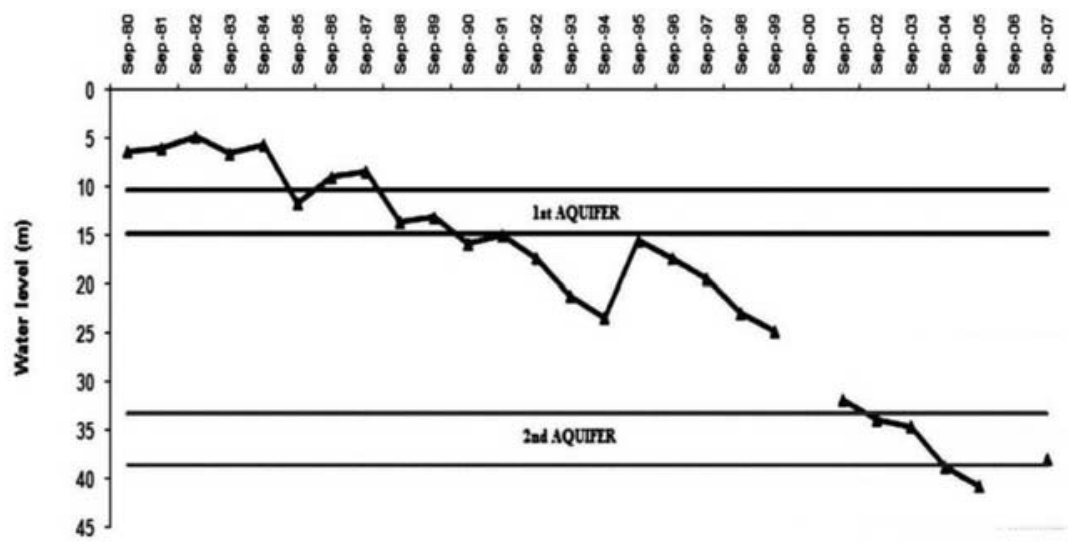

Fig. 6: Ground water table fluctuations with time in Farsala site (Pz46 borehole). The exhaustion of the first two aquifers is obvious.

$150 \mathrm{~cm}$ (Apostolidis and Georgiou, 2007).

In Stavros small town, the main ground rupture was found westwards the railway line. This tensile rupture has a total length of about 2,100 $\mathrm{m}$, an azimuth of $105^{\circ}$ and a vertical displacement at a rate of $60 \mathrm{~cm}$ (Fig. 5). The trace of the rapture affects road pavements and numerous buildings (Apostolidis and Georgiou, 2007). The buildings founded along the trace of the ruptures present several damages, such as cracks in the stonework, distortions in doors, windows, stockyards and pavements. Also, several ground ruptures are located at the south of the town, intersecting cultivated areas.

\section{Correlation of land subsidences with overexploitation of ground water}

In order to correlate the land subsidences phenomena in the wider study area of Stavros - Farsala with the overexploitation of the aquifers, the loggings of water wells were evaluated. According to loggings from Farsala region (water well PZ6), the first aquifer is located at a depth of $10.3 \mathrm{~m}$ to 14.8 $\mathrm{m}$, and consists of sand and gravel. The second aquifer consists of conglomerates and is located at depth $33.3 \mathrm{~m}$, with a mean thickness $5.2 \mathrm{~m}$. Respectively in Stavros site, the logging of water well D34 revealed that the first unconfined aquifer starts from the surface up to a depth of $2.6 \mathrm{~m}$. The second confined aquifer is located at a depth from $5.6 \mathrm{~m}$ to $8.7 \mathrm{~m}$, while a third aquifer, consisting of quaternary deposits, appears from $13.3 \mathrm{~m}$ to $15.8 \mathrm{~m}$.

The diagram of Figure 6 correlates the water tables fluctuations in respect to time in Farsala site. It reveals that from 1984 until 2005 the ground water level was dramatically decreased. The first aquifer was completely drained, at September 1991, as the ground water level reached the depth of 15.82 $\mathrm{m}$, and the second one at September 2005, as the water level reached the $38.5 \mathrm{~m}$ in depth. Respectively, in the case of Stavros site, the first and second aquifers were drained in September 1976 (Fig. 6). The drawdown of the ground water level kept on going until September 1978 (depth of ground water level $15.45 \mathrm{~m}$ ). Finally, at September 2001, with only a few recharges the ground water level reached the depth of $22.15 \mathrm{~m}$ and all three aquifers were drained. The thorough examination of the data referring to ground water level and rainfall reveals that the mean annual drawdown is roughly constant for all water wells in the study area with a value of $60 \mathrm{~cm} /$ year.

From the above discussion it is obvious that the biggest part of the aquifers in Thessaly plain is 


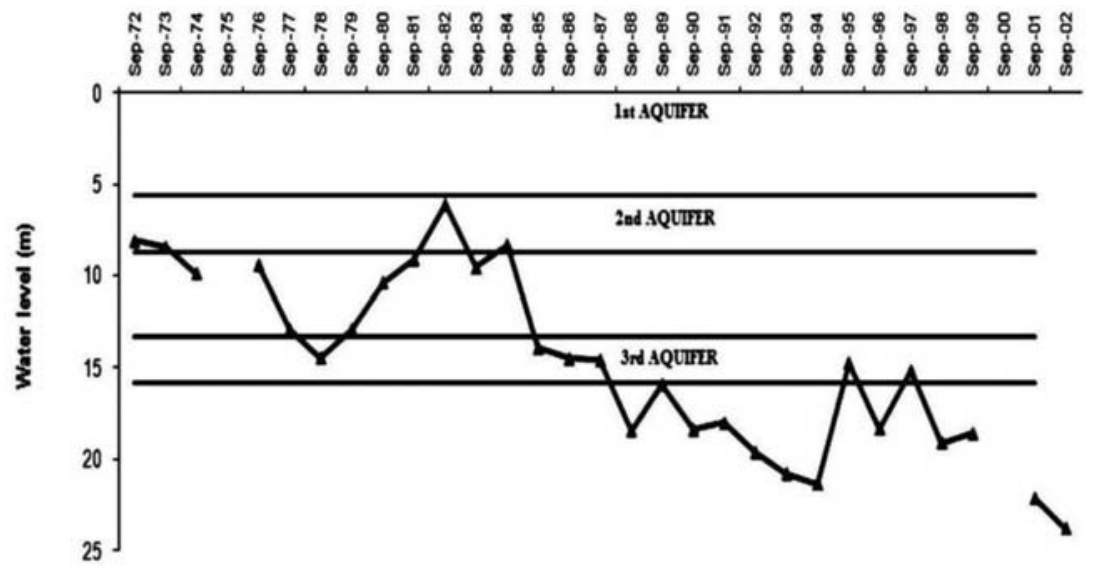

Fig. 7: Ground water table fluctuations with time in Stavros site (D34 borehole). The exhaustion of the first three aquifers is obvious.

under a status of over exploitation, following by a continuous lowering of the ground water level year by year. What differs locally is the intension of overexploitation and the time of the beginning of the ground water table lowering.

\section{Conclusions-Results}

The majority of the aquifers in Thessaly plain are under a regime of overexploitation, resulting in a systematic drawdown of the ground water level. In Farsala - Stavros subplain the consistent overexploitation led to the complete draining of the overlay shallow unconfined aquifer and the progressive drawdown of the successive confined - artesian aquifers. This phenomenon resulted to the compaction of the compressible intercalated clayey horizons, and the manifestation of intensive land subsidence since 2002 .

Land subsidence phenomena become visible on the margins of the basin, with the form of surface ruptures that cause failures in residences and other buildings but also in the street pavements. The geotechnical and hydrogeological parameters of deformed formations contribute to the mechanism of subsidences manifestation. The subsidence deformations, usually take place in an area with alternations of impermeable to semi-permeable compressed formations, such as silty clays to clayey silts, with permeable ones, like sandy to silty sandy horizons.

Because of the increasing need for water, especially for irrigation purposes during the summer period, the reactivation of existing ground ruptures and also the manifestation of new ones are considered to be very possible. The rational exploitation of aquifers in combination with their artificial enrichment will cause progressive increase of ground water level and suspension of the subsidence phenomenon.

\section{References}

Andronopoulos V., Rozos D. Hatzinakos I. I., 1991. Subsidence Phenomena in the Industrial Area of Thessaloniki-Greece. 4th International Symposium on Land Subsidence, IAHS, UNESCO, May 1217, 1991, Houston, Texas, USA.

Apostolidis E., Georgiou H., 2007. Engineering Geological of the surface ground ruptures in Thessalia 
basin sites. Recording and, documentation. Institute of Geology and Mineral Exploration (IGME), unpublished report (in Greek).

I.G.M.E., 1969. Geological map of Greece, Farsala Sheet (scale 1:50.000), Athens, I.G.M.E. Publications.

Kallergis G., 1971. Ground subsidences during the drawdown of artesian aquifers due to their limited elasticity (in Greek). Technika Chronika magazine, pp. 599-602. Athens.

Kallergis G., 1973. Hydrogeological study in sub-basin of Kalampaka (Western Thessaly). Institute of Geology and Mineral Exploration (IGME), unpublished report (in Greek), vol. XIV, No 1, Athens.

Li C., Tang X., Ma T., 2006. Land subsidence caused by groundwater exploitation in the Hangzhou-Jiaxing-Huzhou Plain, China, Hydrogeology Journal 14:1652-1665.

Liu C., Pan Y., Liao J., Huang C., Ouyang S., 2004. Characterization of Land Subsidence in the Choshui River alluvial fan, Taiwan, Environmental Geology 45:1154-1166.

Loupasakis C., Rozos D., 2009. Land Subsidence Induced by Water Pumping in Kalochori Village (North Greece) - Simulation of the Phenomenon by Means of the Finite Element Method. Quarterly Journal of Engineering Geology and Hydrogeology, Geological Society of London, 42, pp. 369-382.

Marinos P., Thanos M., Perleros V., Kavadas M., 1995. Water dynamic of Thessaly basin and the consequences from its overexploitation. Proceedings of the $3^{\text {rd }}$ Hydrogeological Congress (in Greek), Heraklion Crete.

Marinos P., Perleros V., Kavadas M., 1997. Deposited and karsic aquifers of Thessaly plain. New data for the status of their overexploitation. Proceedings of the $4^{\text {th }}$ Hydrogeological Congress (in Greek). Athens.

Mariolakos H., Lekkas S., Papadopoulos T., Alexopoulos A., Spyridonos E., Mandekas I., Andreadakis E., 2001. Underground tectonic structure in Farsala plain (Thessaly) as a determinative factor of the formation of the hydrogeological conditions of the area. Proceedings of the 9th Congress of Greek Geological Society (in Greek).

Rozos D., Tzitziras A., 2002. Report of the Engineering geological examination of ground water in Farsala area. Institute of Geology and Mineral Exploration (IGME).Unpublished report (in Greek).

Rozos D., 2007. Landslides, Subsidences and Settlement in textbook of Engineering Geology I. 352pp (in Greek). Lab. of Eng. Geology and Hydrology, School of Mining and Metallurgical Engineering, NTUA, Athens.

Serva L., Brunamonte F., 2006. Subsidence in the Potina Plain, Italy, Bull Eng Geol Env 66:125-134.

Shi X., Xue Y., Wu Z., Ye S., Zhang Y., Wei Z., Yu Z., 2007. Characterization of regional land subsidence in Yangtze Delta, China: the example of Su-Xi-Chang area in the city of Shanghai, Hydrogeology Journal 16:593-607.

Soulios G., 1997. Subsidence de terrains alluviaux dans le sud-est de la plaine de Thessalie, Grèce. Proceedings International Symposium on Engineering Geology and the Environment. Balkema, Rotterdam.

Soulios G., 1980. Subsidences of recent deposits due to pumping of underneath aquifers An example from Greek territory. Technika Chronika magazine, Athens.

Xue Y., Zhang Y., Ye S., Wu Z., Li Q., 2005. Land subsidence in China. Environmental. Geology 48:713720 . 